\title{
THE INITIATION OF THE DECIDUAL CELL REACTION IN THE UTERUS OF THE AGED MOUSE
}

\author{
G. A. FINN \\ Department of Biological Sciences, Wye College (University of London), \\ Ashford, Kent
}

(Received 18th October 1965)

\begin{abstract}
Summary. Groups of old and young mice were ovariectomized and injected with hormones on a schedule to mimic the endocrine conditions of pregnancy. An artificial decidual stimulus, either trauma or the intraluminal injection of arachis oil, was applied to the left horn of the uterus and the decidual response assessed.

Following trauma, the uteri of the old mice produced significantly smaller deciduomata than those produced in the young mice. After the injection of oil there was no decidual response in the old mice, whereas in the young mice there was a good reaction in seven out of eleven animals.

It is concluded that the ability to form decidual tissue is considerably reduced in old mice, and it is suggested that this may be a significant factor in the senile reduction of litter size.
\end{abstract}

\section{INTRODUCTION}

In many polytocous mammals the number of young born in each litter becomes smaller as the mother ages. In mice the decline starts at about 9 months, and by the time a mother is 18 months old litters are very rare or the production of young has ceased completely (Bittner, 1936; Biggers, Finn \& McLaren, 1962). This senile drop in fecundity is correlated with advancing age and not advancing parity (Finn, 1963). It has been suggested that the most likely cause of the drop in litter size is failure of the old uterus to maintain all the fertilized eggs. Positive evidence in favour of this suggestion is the presence of regressing implantation sites in old pregnant uteri (Sugiyama, 1961; Biggers, Finn \& McLaren, 1962; Finn, 1962) and a disparity between numbers of corpora lutea and size of litters in old mice (McDowell \& Lord, 1925). An alternative possibility, declining numbers of oocytes in the aged ovary, has been investigated by Jones \& Krohn (1961) who concluded that the senile decline in litter size is not primarily due to decreasing numbers of oocytes. They suggest that the cause of the decline in fertility is more likely to be found in the hormonal control of the ovary or in the uterine environment.

During the period of implantation in the mouse the uterus, in response to the stimulus of the blastocyst, undergoes a series of morphological changes 
with the formation of an implantation chamber surrounded by a mass of decidual cells formed in the stroma of the endometrium. This implantation or decidual reaction only occurs when the uterus is under very precise hormonal control by the ovary. Failure of this reaction could be a significant factor in declining litter size. If so, three possibilities could account for the failure: (1) inherent inability of the aged uterus to react effectively to a decidual stimulus; (2) deficiency in the decidual stimulus due to ageing of the blastocyst; and (3) incorrect hormone levels acting on the uterus.

The object of the present experiments was to investigate the first of these, that is the capacity of the aged uterus to undergo the decidual cell reaction.

It has been known for many years that the uterus of a pregnant or pseudopregnant mouse can be induced by an artificial stimulus to undergo a decidual cell reaction. The original stimulus for this was traumatization of the endometrium (Loeb, 1908; Parkes, 1929; Selye \& McKeown, 1935). However, it has recently been shown that the intra-uterine injection of oil also acts as a decidual stimulus, which on the basis of histochemical (Finn \& Hinchliffe, 1964, 1965) and endocrinological (Finn, 1965) studies seems to resemble more closely the natural stimulus provided by the blastocyst. The uterus responds to the oil with the formation along its length of several discrete decidual swellings, each with an internal structure closely resembling an implantation chamber. Thus, it is possible, by using an artificial stimulus, to study the reaction of the uterus uncomplicated by any effect of ageing of the blastocyst. Furthermore, it is also possible to control the endocrine environment of the uterus artificially, so as to rule out any effect of hormonal imbalance in the aged animal. This can be achieved by removing the ovaries of the mice and injecting them with exogenous hormones on a schedule to mimic the conditions of pregnancy.

\section{MATERIALS AND METHODS}

Mice of the GF1 strain were used. Groups of old and young mice were compared for their ability to react to two artificial decidual stimuli, trauma and the intra-uterine injection of oil. The 'old' groups consisted of animals removed from the breeding colony after they had produced six litters and then kept until they were 14 to 16 months old. The other groups consisted of young mice, kept virgin until they were 4 to 5 months old.

Pilot experiments to determine an optimum experimental schedule for the production of deciduomata were performed on young mice and the following schedule adopted. For convenience the timing is started from the day on which ovariectomy is performed.

\section{Experimental schedule}

Day 1: Ovariectomy through the dorsal wall under Avertin anaesthesia. The ovaries were fixed in Bouin's fluid and examined histologically to see whether oogenesis was still occurring.

Days 3, 4 and 5: Subcutaneous injection of $0.1 \mu \mathrm{g}$ oestradiol in $0.1 \mathrm{ml}$ arachis oil daily. 
Days 7 to 13: Subcutaneous injection of $1 \mathrm{mg}$ progesterone in $0.05 \mathrm{ml}$ arachis oil/day.

Day 10: Subcutaneous injection of $0.025 \mu \mathrm{g}$ oestradiol in $0.05 \mathrm{ml}$ arachis oil at 09.30 hours.

Day 10: Decidual stimulus applied to the left horn of the uterus under Avertin anaesthesia between 16.15 and 16.30 hours.

Day 14: Mice killed by cervical dislocation.

The uteri were removed and inspected for the presence of deciduomata. It is easy to see with the naked eye whether there has been a decidual response by this time. The uterine horns were dissected free of adherent tissue and weighed separately on a torsion balance.

The investigation consisted of two separate experiments. In the first the decidual stimulus was three transverse crushes with a haemostat, whilst in the second $0.03 \mathrm{ml}$ of arachis oil was injected into the uterus through the uterotubal junction. In each experiment there were two replicates containing equal numbers of old and young mice taken at random from the parent population.

In the groups in which trauma was used as a decidual stimulus, the response is limited to the site of crushing and there is never any response in the right unstimulated horn. It is possible, therefore, to use the weight of the right horn as an estimate of the unstimulated weight of the left and thus by subtraction to get an estimate of the increase in weight of the uterine horn due to deciduoma formation.

In the groups in which intraluminal injection of oil was used as a stimulus, a complication arises due to the fact that in a few animals (four out of eleven) some of the oil passed from the left horn through the cervix and stimulated deciduoma formation in the right horn also. In these cases it is obviously not possible to use the weight of the right horn as an estimate of the unstimulated weight of the corresponding left horn. However, in the present experiments, seven out of the eleven oil-injected young mice did not respond in the right horn, so that the mean of these gives a fairly close estimate from which to obtain the increase in weight of the other four.

\section{Histochemistry}

As a check on the reaction of the uterus to oil, a further eight old mice were treated as before but killed on Day 12, that is on the second day after the injection of oil, and the treated uteri examined for alkaline phosphatase.

It has previously been demonstrated that a decidual response to oil is clearly shown at this time by a dense reaction for the enzyme in the stroma of the endometrium (Finn \& Hinchliffe, 1964).

\section{RESULTS}

The histological appearance of the old ovaries resembled that found by other workers (Loeb, 1948; Green, 1957). Large numbers of moderate-sized corpora lutea were present together with follicles in various stages of development. Lipochrome cells, as described previously by Fekete (1946), were also found. 
Decidual response to trauma

Both the young and the old mice responded to crushing (Table 1). However, the increase in weight of the uterus due to decidual cell formation was significantly greater in the young than in the old animals.

TABLE 1

RESPONSE OF UTERUS TO TRAUMATIZATION OF THE LEFT HORN

\begin{tabular}{l|c|c}
\hline & Young & Old \\
\hline $\begin{array}{l}\text { No. of mice } \\
\text { No. of mice with positive } \\
\text { response in left horn }\end{array}$ & 10 & 10 \\
$\begin{array}{l}\text { Mean weight of left horns } \\
\text { Mean weight of right horns }\end{array}$ & $104 \cdot 6 \pm 10.5$ & $89.5 \pm 7.8$ \\
$\begin{array}{l}\text { Mean increase in weight of } \\
\text { left horn (mg) }\end{array}$ & $67.4 \pm 9.93$ & $36.5 \pm 7.12$ \\
\hline
\end{tabular}

Significance of the difference of the mean increase in weight between the two groups: $t_{18}=2.53 ; 0.02<P<0.05$.

Intra-uterine injection of oil

None of the uteri of the old mice showed macroscopic signs of deciduomata in either horn after the instillation of arachis oil. On the other hand, seven out of the eleven young mice had clearly visible responses in the left horn and, of these, four also had deciduomata in the right. The difference in the response of the two groups is reflected in the weight increases. Whilst in the young

TABLE 2

RESPONSE OF UTERUS TO INJECTION OF ARACHIS OIL $(0.03 \mathrm{ml})$ INTO LEFT HORN

\begin{tabular}{|c|c|c|}
\hline & roung & old \\
\hline $\begin{array}{l}\text { No. of mice } \\
\text { No. of mice with positive re- } \\
\text { sponse in: (a) left horn } \\
\text { (b) right horn }\end{array}$ & $\begin{array}{r}11 \\
7 \\
4\end{array}$ & $\begin{array}{c}10^{*} \\
0 \\
0\end{array}$ \\
\hline $\begin{array}{l}\text { Mean weight of all left horns } \\
\text { Mean weight of all right horns } \\
\text { Mean weight of seven non- } \\
\text { responding right horns }\end{array}$ & $\begin{array}{l}80 \cdot 5 \pm 19 \cdot 3 \\
53 \cdot 0 \pm 12 \cdot 1 \\
38 \cdot 3 \pm 5 \cdot 8\end{array}$ & $\begin{array}{l}73 \cdot 7 \pm 5 \cdot 8 \\
72 \cdot 4 \pm 5 \cdot 5\end{array}$ \\
\hline $\begin{array}{l}\text { Mean increase in weight of left } \\
\text { horn (mg) }\end{array}$ & $42 \cdot 3 \pm 19 \cdot 2$ & $1 \cdot 3 \pm 0.66$ \\
\hline
\end{tabular}

* One mouse in this group died before completion of the experiment.

Significance of the difference of the mean increase in weight between the two groups: $t_{19}=9 \cdot 2 ; P<0.001$.

animals there was an increase of over $100 \%$ in the weight of the treated horn due to decidual formation, there was no significant increase in the old. Furthermore, histochemical examination of the additional seven old mice showed no accumulation of alkaline phosphatase in the stroma, thus confirming that the uteri of old mice do not respond to the intra-uterine injection of oil. 
The mean weights of the uteri of the old mice in the second experiment are very heavy in comparison with the corresponding non-decidualized horns of the young mice. This is probably due to the presence of collagen which has been shown to accumulate in the uteri of old mice (Finn, Fitch \& Harkness, 1963). In the first experiment, the right horns of the old animals are also significantly heavier than the right horns of the young animals, but they are significantly lighter than the right or left horns of the old animals in the second experiment. It is not strictly valid to compare mean weights from the two experiments as they were planned and executed separately. Nevertheless, such a difference is unexpected and may represent a true biological effect of the treatment; if so, it must be an effect only associated with aged uteri because the mean weights of the non-responding right horns of the young mice are almost identical in the two experiments.

\section{DISGUSSION}

From the results of this experiment it is apparent that the ability to respond to an artificial decidual stimulus is considerably reduced in the aged uterus. This supports the view that the uterus is responsible, at least in part, for the reduction of litter size in old mice, either by preventing implantation completely or by undergoing an inadequate implantation reaction. In the latter case it is reasonable to assume that the blastocyst would be unable to develop and grow normally. It is, in fact, typical of middle aged mice (about 10 months) to find regressing implantation sites together with normal embryos in the uterus (Finn, 1962). Presumably the loss of the ability to undergo the decidual cell reaction is a gradual process, so that in middle age the response to some blastocysts is adequate for their development, whilst inadequate to others.

\section{ACKNOWLEDGMENTS}

I would like to express my thanks to Dr Anne McLaren of the Institute of Animal Genetics and Dr A. H. Sykes of Wye College for help in the preparation of the manuscript. I am also grateful to the M.R.G. for financial assistance.

\section{REFERENCES}

Biggers, J. D., Finn, C. A. \& MaLaren, A. (1962) Long term reproductive performance of female mice. II. Variation of litter size with parity. 7. Reprod. Fert. 3, 313.

BitTNER, J. J. (1936) Differences observed in an inbred albino strain of mice following a change of diet. I. Litter size. Nain. Bull., Roscoe B. Jackson Memorial Lab. No. 2, p. 3.

Fekete, E. (1946) A comparative study of the ovaries of virgin mice of the dba and C57 Black strains. Cancer Res. 6, 263.

Fins, C. A. (1962) Embryonic death in aged mice. Nature, Lond. 194, 499.

Fins, C. A. (1963) Reproductive capacity and litter size in mice: effect of age and environment. 7. Reprod. Fert. 6, 205.

Fins, G. A. (1965) Oestrogen and the decidual cell reaction of implantation in mice. F. Endocr. 32, 223.

Finn, C. A., Frtch, S. M. \& Harkness, R. D. (1963) Collagen content of barren and previously pregnant uterine horns in old mice. F. Reprod. Fert. 6, 405.

Finn, C. A. \& Hinchuiffe, J. R. (1964) Reaction of the mouse uterus during implantation and deciduoma formation as demonstrated by changes in the distribution of alkaline phosphatase. 7. Reprod. Fert. 8, 331. 
Finn, C. A. \& Hinchliffe, J. R. (1965) Histological and histochemical analysis of the formation of implantation chambers in the mouse uterus. $\mathcal{F}$. Reprod. Fert. 9, 301.

GreEn, J. A. (1957) Some effects of advancing age on the histology and reactivity of the mouse ovary. Anat. Rec. 129, 333.

Jones, E. C. \& KroHN, P. L. (1961) The relationships between age, numbers of oocytes and fertility in virgin and multiparous mice. F. Endocr. 21, 469.

LOEB, L. (1908) The experimental production of the maternal placenta, and the function of the corpus luteum. F. Am. med. Ass. 50, 1897.

LOEB, L. (1948) Ageing processes in the ovaries of mice belonging to strains differing in the incidence of mammary carcinoma. Archs Path. 46, 401.

MaDowell, E. C. \& LORD, E. M. (1925) The number of corpora lutea in successive mouse pregnancies. Anat. Rec. 31, 131.

Parkes, A. S. (1929) The function of the corpus luteum. II. The experimental production of placentomata in the mouse. Proc. R. Soc. B, 104, 183.

SELYe, H. \& McKeown, T. (1935) Studies on the physiology of the maternal placenta of the rat. Proc. R. Soc. B. 119, 1.

Sugryama, T. (1961) Reproductive power of mother mice of different ages. Acta Sch. med. Univ. Kioto, $37,172$. 